\title{
INFEKSI MYCOBACTERIOSIS PADA IKAN BUDIDAYA DI INDONESIA
}

\author{
Hambali Supriyadi \\ Pusat Riset Perikanan Budidaya \\ Jl. Ragunan 20, Pasar Minggu, Jakarta Selatan 12540 \\ E-mail: hambali@ cria.indosat.net.id
}

\section{ABSTRAK}

Penyakit akibat infeksi bakteri telah banyak ditemukan pada usaha budidaya ikan baik di dunia termasuk di Indonesia. Penyakit akibat infeksi bakteri Aeromonas hydrophila telah banyak menimbulkan kerugian padabudidaya ikan mas (Cyprinus carpio), gurame (Osphronemus gouramy), dan ikan lele (Clarias batrachus). Penyakit tersebut juga telah menimbulkan kerugian yang tidak sedikit pada usaha budidaya ikan hias. Penyakit lain yang sekarang menjadi masalah yang tidak ringan pada usaha budidaya ikan adalah penyakit akibat infeksi bakteri Mycobacterium fortuitum. Penyakitnya terkenal dengan sebutan "mycobacteriosis" atau sering juga di istilahkan dengan "fish tuberculosis". Lebih dari 150 jenis ikan baik ikan air tawar maupun ikan laut dapat terinfeksi oleh penyakit tersebut. Penyakit tersebut selain dapat menginfeksi ikan dapat juga menginfeksi manusia, terutama pada pembudidaya yang dalam menangani ikan yang terinfeksi oleh penyakit ini tidak dilakukan dengan hati-hati. Di Indonesia telah dilakukan beberapa penelitian tentang jenis ikan yang terinfeksi maupun sebarannya terutama di Pulau Jawa. Telah diketahui bahwa penyakit ini terutama menginfeksi ikan gurame (Osphronemus gouramy). Gejala klinis serangannya serta cara untuk diagnosa dan deteksi bagi penyakit tersebut telah banyak diteliti. Treatment/pengobatan terhadap penyakit tersebut relatif agak susah, jadi tindakan yang lebih baik dilaksanakan adalah tindakan pencegahan, dan segera memusnahkan dengan cara dikubur dan atau dibakar, apabila kita menemukan ikan yang terinfeksi oleh penyakit tersebut.

KATAKUNCl: Mycobacteriosis, Mycobacterium fortuitum, diagnosa, deteksi, ikan inang, sebaran, infeksi pada manusia.

\section{PENDAHULUAN}

Penyakit ikan akibat infeksi bakteri telah banyak menyebar di Indonesia. Penyakit tersebut selain dapat menimbulkan kerugian berupa kematian ikan juga dapat menurunkan kualitas ikan yaitu kesegaran, warna, dan cacat tubuh yang kesemuanya tentu saja akan berpengaruh pada harga jual/nilai ekonomis ikan tersebut. Adapun kematian yang ditimbulkannya menurut Supriyadi \& Taufik (1981), Taufik (1992), Supriyadi \& Rukyani (1990) dapat mencapai 50\%-100\%

Jenis-jenis bakteri penginfeksi ikan budidaya sangat banyak seperti yang dikemukakan oleh Supriyadi et al. (2005) telah melakukan penelitian keragaan penyakit akibat infeksi bakteri pada ikan nila (Oreochromis niloticus) yang dibudidayakan pada Keramba Jaring Apung (KJA), banyak sekali bakteri yang dapat menginfeksi ikan nila namun pada umumnya didominasi oleh Aeromonas hydrophila, Pseudomonas sp., Alteromonas shigelloides, dan Streptococcus sp. Bakteri Aeromonas hydrophila juga merupakan masalah pada budidaya ikan mas (Cyprinus carpio) dan lele (Clarias batrachus). Bakteri Edwardsiella tarda dan Edwardsiella ictaluri juga merupakan bakteri yang banyak menimbulkan masalah pada budidaya ikan lelelelean termasuk pangasid.

Penyakit bakterial yang disebabkan oleh bakteri Mycobacterium sp. telah banyak menginfeksi terutama pada ikan konsumsi dan ikan hias baik ikan air tawar maupun ikan air laut (Nigrelli \& Vogel, 1963; Chinabut et al., 1990). Penyakit tersebut dapat menimbulkan kematian lebih dari 20\%pada ikan gabus (Limsuwan et al., 1983) dan selain itu juga, menurunkan mutu ikan itu sendiri. Gejala klinis yang dapat diamati dari ikan yang terinfeksi penyakit tersebut antara lain: mata menonjol (exophthalmia), adanya benjolan pada tubuh dan terdapatnya bintil-bintil berwarna keputihan (tubercle) pada daging, ginjal, hati, dan limfa. Mycobacteriosis atau sering juga disebut dengan tuberculosis pada ikan merupakan penyakit yang sifat serangannya kronis dan dapat menginfeksi berbagai spesies ikan baik ikan laut maupun ikan air tawar. Bahkan telah dilaporkan lebih dari 150 spesies ikan dapat terinfeksi oleh penyakit tersebut (Frerich, 1993). 
Sedangkan Chinabut et al. (1990) telah melaporkan ada 151 spesies ikan dapat terinfeksi mycobacteriosis, terutama ikan gabus (Channa striatus) dan ikan cupang (Betta splendens). Adapun jenis-jenis bakteri mycobacterium yang sering menginfeksi ikan adalah M ycobacterium marinum yang banyak menginfeksi ikan laut, M ycobacterium fortuitum yang terutama menginfeksi ikan air tawar dan Mycobacterium chelonei yang pertama kali diisolasi dari sejenis kura-kura.

\section{JENIS-JENIS IKAN INANG}

Telah dikatakan di atas bahwa sejumlah 151 spesies ikan baik ikan laut maupun ikan air tawar sudah diketahui dapat terinfeksi oleh penyakit ini. Di Indonesia, Supriyadi et al. (2003) telah mengisolasi Mycobacterium sp. dari berbagai ikan budidaya yaitu di antaranya: ikan mas (Cyprinus carpio), ikan nila (Oreochromis niloticus), ikan gurame (Osphronemus gouramy). Namun demikian bateri tersebut tidak ditemukan pada ikan lele (Clarias batrachus). Prevalensi paling tinggi penyakit ini terdapat pada ikan gurame.

Infeksi penyakit mycobacteriosis pada ikan laut di Indonesia belum ada informasi yang diperoleh karena belum ada penelitian yang dilaksanakan untuk mengetahui hal tersebut. Sebenarnya sudah waktunya untuk dilakukan penelitian tersebut, mengingat sudah banyak ikan laut yang sekarang sudah dibudidayakan. Jenis-jenis ikan laut yang diketahui telah terinfeksi oleh mycobacteriosis menurut Kane et al. (2007) di antaranya: Atlantic menhaden (Brevoortica tyrannus), Blueback herring (Alosa aestivalis), Winter flounder (Pleuronectes americanus), Striped killifish (Fundulus majalis), Mummichog ( $F$.

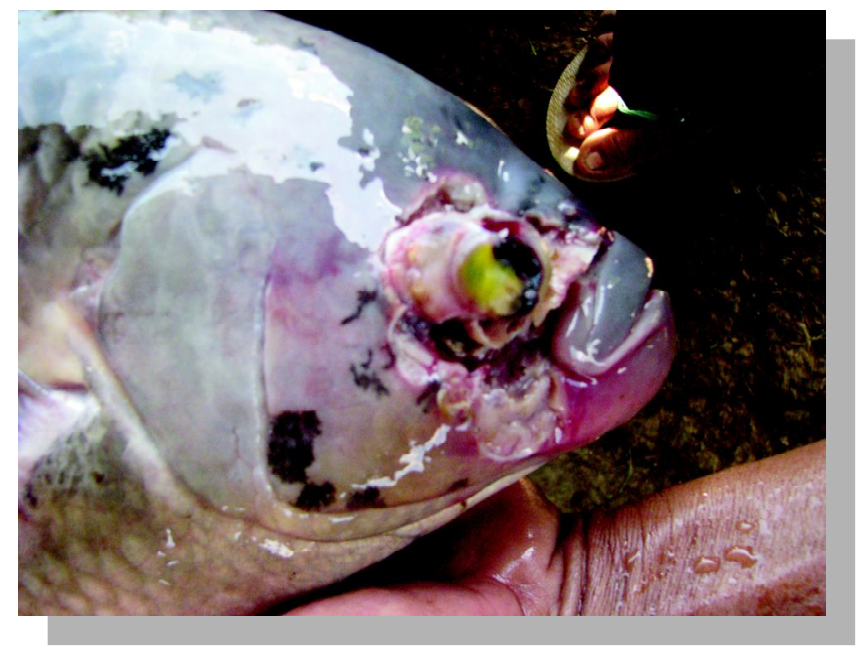

heteroclitus), Largemouth bass (Micropterus salmoides), Weakfish (Cynoscion regalis), Spot (Leiostomus xanthurus), dan White perch (M orone americana)

\section{GEJALA INFEKSI MYCOBACTERIOSIS PADA IKAN}

Infeksi penyakit ini pada ikan yang berumur muda/ benih, mungkin tidak akan menunjukkan gejala klinis karena penyakit ini sifat serangannya kronis dengan efek yang sangat lamban. Pada ikan besar infeksi terjadi apabila ikan mengalami stres oleh suatu sebab. Gejala awal yang tampak antara lain nafsu makan berkurang, pembengkakan pada kulit, mata menonjol, lesu, dan borok mungkin akan timbul kemudian. Apabila ikan dibedah biasanya akan tampak tubercle/granuloma yaitu bintil-bintil berwarna putih yang terdapat pada daging dan organ dalam seperti hati, limpha, dan ginjal (Gambar 1).

\section{DIAGNOSA PENYAKIT}

Diagnosa pendugaan dari penyakit ini biasanya didasarkan pada adanya tubercle/granuloma yang biasa diamati setelah kita membedah ikan yang diduga terinfeksi berdasarkan gejala-gejala klinis luar yang tampak seperti telah diuraikan di atas. Apabila granuloma belum terbentuk dengan jelas maka kita bisa mengamatinya di bawah mikroskop dari preparat smear/apus yang diambil dari jaringan hati, limpha, dan ginjal. Granuloma juga kadang-kadang bias terdapat pada luka kulit. Setelah itu, diyakinkan dengan pewarnaan acid fast yang sediaannya diambil dari jaringan yang diduga terinfeksi. Apabila terdapat bakteria yang berbentuk batang terwarnai merah atau pink dengan latar belakang hijau muda, maka tandanya bahwa ikan tersebut positif terinfeksi mycobacteriosis.

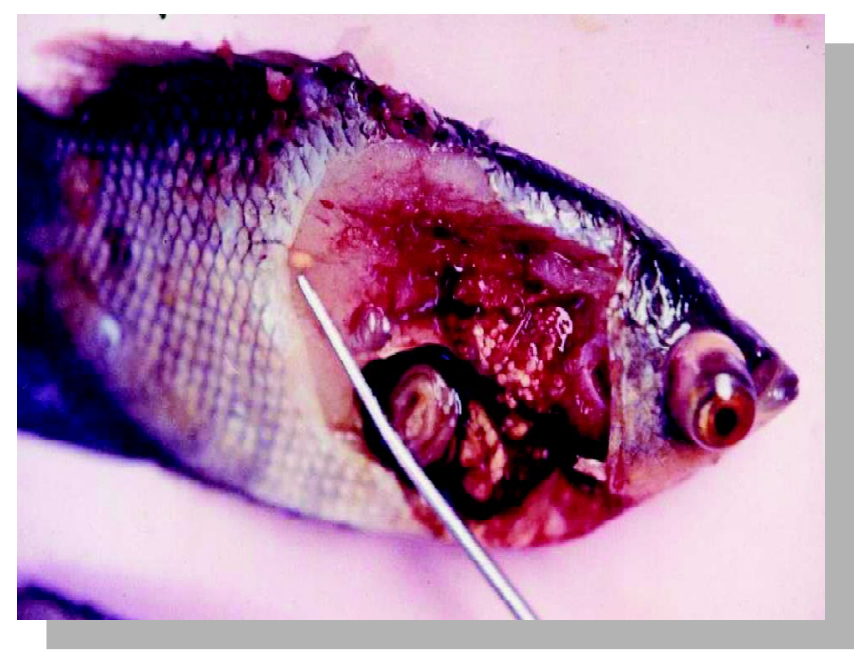

Gambar 1. Gejala klinis ikan yang terinfeksi mycobacteriosis berupa mata menonjol (exophthalmia) dan terdapatnya tubercle/granuloma pada daging, limpa, dan hati 
Untuk lebih meyakinkan maka dari ikan yang diduga terinfeksi kemudian diisolasi bakterinya dengan menggunakan media spesifik, yang dilanjutkan dengan mengidentifikasi bakteri biasanya berdasarkan karakterisasi biokimia. Metoda deteksi yang lebih cepat sekarang sudah banyak dikembangkan yaitu antara lain dengan menggunakan metode berdasar DNA, atau lebih popular dengan metode PCR. Kolk et al. (1992) telah melakukan deteksi mycobacterium dengan menggunakan PCR dan sistem deteksi nonradioaktif. Demikian juga Novita (2008) telah melakukan modifikasi metode PCR untuk deteksi mycobacteriosis yang ternyata memiliki sensitivitas yang cukup baik.

\section{SEBARAN PENYAKIT DI INDONESIA}

Belum banyak penelitian tentang sebaran penyakit ini dalam cakupan luasan yang mencakup seluruh wilayah Indonesia. Supriyadi et al. (2003) telah melakukan penelitian tentang sebaran mycobacteriosis di sentrasentra budidaya di Pulau Jawa. Penyakit tersebut ternyata telah menyebar pada hampir semua kabupaten/kota yang diteliti (Tabel 1). Prevalensi serangan yang paling tinggi terdapat di Jawa Tengah yaitu di Kabupaten
Tabel 1. Sebaran mycobacteriosis pada masing-masing provinsi di wilayah Pulau Jawa

\begin{tabular}{llc}
\hline \multicolumn{1}{c}{ Provinsi } & \multicolumn{1}{c}{ Kabupaten } & $\begin{array}{c}\text { Status keberadaan } \\
\text { mycobacteriosis }\end{array}$ \\
\hline Jawa Barat & Tasikmalaya & Positif \\
& Cianjur & Positif \\
& Sukabumi & Positif \\
\hline Banten & Serang & Positif \\
& Pandeglang & Positif \\
\hline DKI Jakarta & Jakarta Selatan & Negatif \\
& Jakarta Timur & Positif \\
\hline Jawa Tengah & Purbalingga & Positif \\
& Banyumas & Positif \\
& Cilacap & Positif \\
\hline DI Jogjakarta & Sleman & Positif \\
& Bantul & Positif \\
\hline Jawa Timur & Malang & Positif \\
& Blitar & Positif \\
& Tulung Agung & Positif \\
& Madiun & Positif \\
\hline
\end{tabular}

Tabel 2. Hasil seleksi pertumbuhan pada media spesifik dan deteksi dengan PCR

\begin{tabular}{|c|c|c|c|c|c|}
\hline \multirow{2}{*}{ Asal isolat } & \multirow{2}{*}{ Organ } & \multicolumn{3}{|c|}{ Seleksi media } & \multirow{2}{*}{ PCR 210 bp } \\
\hline & & Souton & Lowenstein & Mac konkay & \\
\hline \multicolumn{6}{|l|}{ Jawa Timur } \\
\hline Blitar 1 & Hati & Positif & Positif & Positif & Positif \\
\hline Blitar 2 & Mata & Positif & Positif & Positif & Positif \\
\hline Blitar 3 & Hati & Positif & Positif & Positif & Positif \\
\hline Blitar 4 & Hati & Negatif & Negatif & Negatif & Negatif \\
\hline Tulung Agung 1 & Hati & Negatif & Negatif & Negatif & Negatif \\
\hline Tulung Agung 2 & Hati & Negatif & Negatif & Negatif & Negatif \\
\hline \multicolumn{6}{|l|}{ Jawa Barat } \\
\hline Tasikmalaya/Cikokol 1 & Hati & Negatif & Negatif & Negatif & Negatif \\
\hline Tasikmalaya/Cikokol 2 & Hati & Negatif & Negatif & Negatif & Negatif \\
\hline Tasikmalaya/M ongor 1 & Hati & Negatif & Negatif & Negatif & Negatif \\
\hline Tasikmalaya/M ongor 2 & Hati & Positif & Positif & Positif & Positif \\
\hline Parung 1 & Hati & Negatif & Negatif & Negatif & Negatif \\
\hline Parung 2 & Hati & Negatif & Negatif & Negatif & Negatif \\
\hline \multicolumn{6}{|l|}{ Jawa Tengah } \\
\hline Purwokerto/Tambak Sogra 1 & Limpha & Positif & Positif & Positif & Positif \\
\hline Purwokerto/Tambak Sogra 2 & Mata & Positif & Positif & Positif & Positif \\
\hline Purwokerto/Tambak Sogra 2 & Spleen & Positif & Positif & Positif & Positif \\
\hline Purwokerto/Karang Salam 1 & Mata & Positif & Positif & Positif & Positif \\
\hline Purwokerto/Karang Salam 1 & Hati & Negatif & Negatif & Negatif & Negatif \\
\hline
\end{tabular}

Sumber: Novita \& Supriyadi (2009) 
Purbalingga, Banyumas, dan Cilacap. Hal ini dirasa cukup menghawatirkan mengingat hampir semua kabupaten di Jawa Timur mendapat pasok benih dari Kabupaten Banyumas dan Purbalingga.

Penelitian yang dilakukan oleh Novita $\&$ Supriyadi (2009) juga menunjukkan bahwa mycobacteriosis masih tersebar baik di Jawa Barat, Jawa Tengah, dan Jawa Timur (Tabel 2). Hanya saja pada penelitian tersebut mycobacteriosis tidak ditemukan di Tulung Agung. Namun demikian dari hasil penelitian Novita \& Supriyadi (2009) juga menunjukkan bahwa prevalensi serangan tertinggi terdapat di Jawa Tengah (Tabel 3).

Tabel 3. Prevalensi penyakit mycobacteriosis pada ikan gurame dideteksi dengan metode PCR

\begin{tabular}{lccc}
\hline Asal daerah & $\begin{array}{c}\text { Jumlah } \\
\text { sampel }\end{array}$ & $\begin{array}{c}\text { Jumlah sampel } \\
\text { yang positif }\end{array}$ & $\begin{array}{c}\text { Prevalensi } \\
\text { (\%) }\end{array}$ \\
\hline Jawa Timur & 6 & 3 & 50 \\
Jawa Barat & 6 & 1 & 16,67 \\
Jawa Tengah & 5 & 4 & 80 \\
\hline
\end{tabular}

Sumber: Novita \& Supriyadi (2009)

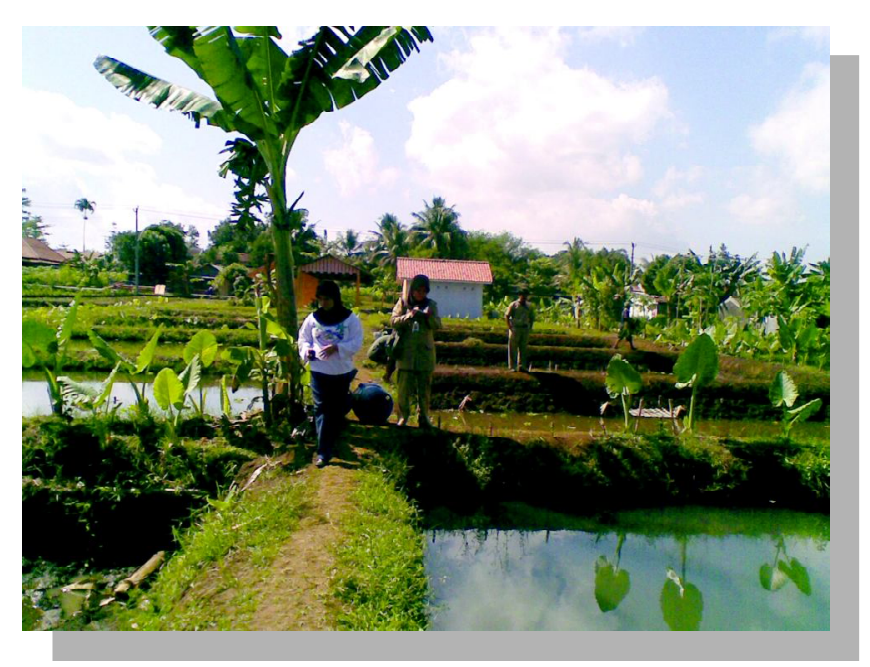

Gambar 2. Lokasi pembudidayaan gurame di Kampung Karangsalam Kabupaten Banyumas

\section{TRANSMISI PADA MANUSIA}

Sering orang bertanya apakah ikan yang sakit tidak menyebabkan penyakit pada manusia?. Jawabannya tergantung pada jenis penyakitnya apakah itu bersifat zoonotik atau tidak. Kalau sifatnya zoonotik maka penyakit pada ikan akan dapat menyebabkan penyakit pada manusia. Bagaimana dengan mycobacteriosis?. Walaupun transmisi dari ikan yang terinfeksi kepada manusia jarang terjadi, namun sebenarnya mycobacteriosis ini tergolong pada penyakit yang sifatnya zoonosis. Jadi kita dalam menangani penyakit ini harus ekstra hati-hati. Karena penyakit yang biasanya menginfeksi ikan ini dapat menyebabkan infeksi kulit pada manusia, terutama pada manusia yang banyak menangani ikan sakit tanpa memperhatikan kebersihan dan kesehatan (Floyd \& Yanong, 2007). Pada beberapa kasus infeksi bakteri sering terjadi karena adanya kontak antara bakteri patogen penginfeksi penyakit dengan luka yang terdapat pada kulit yang tidak segera dicuci dengan menggunakan detergen. Infeksi dicirikan dengan adanya benjolan kecil (pustules) di sekitar tempat kontak tersebut. Pustules tersebut kemudian mengeluarkan cairan yang berwarna putih kekuning-kuningan. Pada individu/manusia yang sehat maka akan sembuh dengan sendirinya. Namun tidak jarang ada laporan bahwa infeksinya pada manusia bisa mengakibatkan infeksi yang serius, dan mengakibatkan terjadinya luka yang dalam dan berkepanjangan.

\section{MANAJEMEN KESEHATAN}

Infeksi mycobacteriosis pada ikan merupakan infeksi yang tidak mudah untuk ditangani/diobati. Oleh karena itu, maka kalau kita menemukan kasus penyakit dengan gejala seperti tersebut di atas maka harus segera dimusnahkan dengan cara dikubur setelah diberi desinfektan. Bak atau kolam bekas ikan yang terinfeksi kemudian dikeringkan dan di desinfeksi. Demikian juga peralatan yang dipakai untuk penanganan ikan sakit tersebut segera dicuci dengan menggunakan deterjen dan juga di desinfeksi. Tangan operator harus segera dibilas dengan menggunakan alkohol 70\% dan dicuci dengan sabun antibakteri.

Mycobacterium pada umumnya sangat resisten terhadap antibakteria pada dosis standar. Oleh karena itu, dosis $10.000 \mathrm{mg} / \mathrm{L}$ klorin diperlukan untuk dapat membunuh bakteri tersebut. Namun demikian mycobacterium sangat sensitif terhadap alkohol 60\%80\%(Floyd \& Yanong, 2007).

\section{DAFTAR ACUAN}

Chinabut, S., Limsuwan, C., \& Chanratchakool. 1990. Mycobacteriosis in the snakehead (Channa striatus). J. Fish Dis., 13: 531-535.

Floyd, R.F. \& Yanong, R. 2007. Mycobacteriosis in Fish. University of Florida IFAS Extention., p. 1-6.

Frerichs, G.N. 1993. Mycobacteriosis: nocardiosis, in Inglis, V., Roberts, R.J. \& Bromage, N. (Eds). Bacterial Diseases of Fish. Blackwell Scientific Publication. Oxford. U.K., p. 219-233. 
Kane, A.S., Stine, C.B., Hungerford., L., Matsche, M., Driscoll, C., \& Baya, A.M. 2007. Mycobacteria as Environmental Porten in Chesapeake Bay Fish Species. Emerg Infect Dis., 13(2): 329-331.

Kolk , A.H.J., Schuitema., A.R.J., Kuijper., S., van Leeuwen., J., Hermans., P.W.M., van Embden, J.D.A., \& Hartskeerl, R.A. 1992. Detection of M ycobacterium tuberculosis in Clinical Samples by Using Polymerase Chain Reaction and a Non-radioactive Detection System. J. of Clinical Microbiology, 30(10): 2567-2575.

Limsuwan, C., Chinabut., S., Pawapuitanon, K., \& Lawhavinit, 0. 1983. Tuberculosis (mycobacteriosis) in snakehead (Ophicephalus striatus). National Inland Fisheries Institute. Technical paper2. Fisheries Department. Bangkok, Thailand.

Nigrelli, R.F., \& Vogel, H. 1963. Spontaneous tuberculosis in fishes and other cold-blooded vertebrates with special reference "Science to M ycobacterium fortuitum
Cruz from fish and human lesions. Zoologica, 48: 130143

Novita, H. \& Supriyadi, H. 2009. Aplikasi Diagnostik Dalam Monitoring mycobacteriosis Pada ikan Gurame (Osphronemus gouramy Lac) di Jawa. Laporan Internal Pusat Riset Perikanan Budidaya, hlm. 1-11.

Supriyadi, H. \& Rukyani, A. 1990. Immunopropilaksis dengan cara vaksinasi pada usaha budidaya ikan. Seminar Nasional Kell, Penyakit Ikan dan Udang, Bogor, 16-18 Januari 1990, $6 \mathrm{hlm}$.

Supriyadi, H., Taufik, P., \& Taukhid. 2003. Karakterisasi Patogen, Inang Spesifik, dan Sebaran Mycobacteriosis. J. Pen. Perik. Indonesia, 9(2): 39-45.

Supriyadi, H., Widiyati., A., Sunarto, A., \& Prihadi, T.H. 2005. Keragaan Penyakit Bakterial Ikan Nila (Oreochromis niloticus) pada Keramba Jaring Apung (KJA) di Lokasi Berbeda. J. Pen. Perik. Indonesia, 11(7): 35-45. 